\title{
IDENTIFIKASI KEANEKARAGAMAN DAN POLA SEBARAN HAMA KUTU PUTIH DAN MUSUH ALAMINYA PADA TANAMAN SINGKONG (Manihot esculenta) DI KABUPATEN BANYUWANGI
}

\section{DIVERSITY AND DISTRIBUTION PATTERNS IDENTIFICATION OF MEALYBUG PESTS AND THEIR NATURAL ENEMIES ON CASSAVA CROPS (Manihot esculenta) IN BANYUWANGI DISTRICT}

\author{
Fitri Nurmasari ${ }^{*}$
}

\begin{abstract}
Diterima : 15 Juli 2020
Disetujui : 23 September 2020
\end{abstract}

Afiliasi Penulis:
1) Universitas PGRI Banyuwangi

\begin{tabular}{l}
\hline Alamat Korespondensi: \\
*onlypieth@gmail.com \\
\hline
\end{tabular}

\section{Cara Sitasi:}

Nurmasari, F. 2020. Identifikasi keanekaragaman dan pola sebaran hama kutu putih dan musuh alaminya pada tanaman singkong (Manihot esculenta) di Kabupaten Banyuwangi: Journal of Tropical Biology 8 (3): 171177

\begin{abstract}
ABSTRAK
Keberlanjutan produksi singkong dalam waktu beberapa tahun terakhir ini terancam dengan adanya invasi kutu putih. Beberapa spesies diantaranya adalah Phenacoccus manihoti, Paracoccus marginatus, dan Ferrisia virgata. Kutu putih singkong merupakan hama baru yang berpotensi menjadi ancaman di pertanaman khususnya tanaman singkong. Salah satu upaya pengendalian hama kutu putih pada tanaman singkong adalah dengan menggunakan musuh alaminya yaitu parasitoid, predator dan patogen. Penelitian ini bertujuan untuk mengetahui keanekaragaman hayati dan pola persebaran kutu putih serta keberadaan musuh alaminya pada tanaman singkong. Penelitian dilakukan pada bulan Maret sampai dengan Agustus 2018 di Kabupaten Banyuwangi. Hasil penelitian menunjukkan bahwa pada sepuluh lokasi di Kabupaten Banyuwangi ditemukan dua spesies kutu putih yaitu P. marginatus dan F. virgata, ditemukan satu spesies predator kutu putih jenis Lacewing hemerobius spp.
\end{abstract}

Kata kunci: identifikasi, hama kutu putih, predator, parasitoid, singkong

\begin{abstract}
Mealybugs invasion is one of some factors that affected the sustainability of cassava production for these recent years. Phenacoccus manihoti, Paracoccus marginatus, and Ferrisia virgata are three common kind of them. One of pest control towards mealybugs invasion is by using their natural enemies such as parasitoids, predators, and pathogens. This research conducted to discover mealybugs and their natural enemies diversity on cassava crops (Manihot esculenta Crantz). This research was held from March to August 2018. The result showed that mealybugs diversity on cassava crops at ten different locations in Banyuwangi District was put on medium category with two mealybugs species found, Paracoccus marginatus and Ferrisia virgata. There is no mealybugs parasitoid found and only one mealybugs predator, Hemerobius spp., found through this research.
\end{abstract}

Keywords: identification, mealybugs, predator, parasitoids, cassava

\section{PENDAHULUAN}

Singkong (Manihot esculenta) berasal dari Benua Amerika khususnya negara Brazil. singkong merupakan tanaman pertanian yang penting di daerah tropis dan subtropis. Tanaman ini berkembang di negara- negara yang terkenal wilayah pertaniannya dan pada tahun 1852, tanaman ini masuk ke Indonesia [1]. Singkong merupakan tanaman yang penting bagi kehidupan manusia. Hal ini dikarenakan tanaman singkong memiliki banyak manfaat, diantaranya berperan sebagai bahan diversifikasi pangan. Selain berperan 
sebagai bahan untuk diversifikasi pangan, singkong juga dimanfaatkan sebagai sumber pakan, bahan baku industri, dan bahan baku bioetanol [2]. Kandungan karbohidrat dalam tanaman singkong sebesar 34,7 gram/100g [3]. Sehingga singkong merupakan tanaman pangan penghasil sumber karbohidrat yang cukup banyak. Dalam dua tahun terakhir ini, keberlanjutan produksi singkong terancam oleh adanya invasi hama asing yaitu kutu putih Phenacoccus manihoti [4][5]. P. manihoti atau kutu putih singkong merupakan hama baru yang berpotensi menjadi ancaman di pertanaman khususnya tanaman singkong. $P$. manihoti berasal dari Amerika Selatan tepatnya Brazil. Pada awal tahun 1970-an, kutu putih $P$. manihoti terbawa masuk ke Afrika dan menyebabkan kegagalan panen dan kelaparan. Hama ini mulai masuk ke Asia pada tahun 2009, pertama kali ditemukan di Thailand yang kemudian segera menyebar ke Kamboja dan Laos [6][7]. Pada tahun 2010, kutu putih $P$. manihoti masuk ke Indonesia dan ditemukan menyerang pertanaman singkong di Bogor [8]. Sebagai wilayah dengan potensi geografis yang sangat mendukung, Kabupaten Banyuwangi merupakan salah satu daerah penghasil singkong yang cukup menjanjikan dengan total jumlah produksi sebanyak 32.358 ton dari 1.688 ha lahan panen pada tahun 2015 [9],sehingga keberadaan hama kutu putih ini salah satu jenis hama pengganggu tanaman singkong adalah kutu putih atau mealybug dari berbagai spesies, antara lain $P$. manihoti, Bemicia tabacci dan lainnya. Dilaporkan adanya serangan hama kutu putih singkong $(P$. manihoti) yang ditemukan pada 2010 di tanaman singkong di Bogor. Serangan $P$. manihoti belum meluas, namun hama ini dapat berkembang dengan cepat dan menyerang pada musim kemarau. Kutu putih singkong dapat berkembang biak tanpa dibuahi oleh jantannya, sehingga perkembangbiakannya cepat dan massif. Tiga spesies yang secara umum menyerang tanaman singkong di berbagai daerah di Indonesia adalah Phenacoccus manihoti, Paracoccus marginatus dan Ferrisia virgata. Serangan kutu putih di Indonesia menjadi masalah yang rumit karena tidak ditemukan adanya musuh alami yang mampu mengurangi atau mengatasi efek serangan hama tersebut. Di daerah asalnya, serangan hama ini dapat dikendalikan dengan adanya musuh alami seperti parasitoid dan predator [10]. Keberadaan kutu putih singkong $P$. manihoti telah menyebabkan kerusakan pertanaman singkong di daerah Afrika dan
Amerika Selatan [11]. Serangan mealybug pada tanaman ditandai dengan munculnya material tebal berwarna putih dan atau hitam pada permukaan daun atau apeks, yang merupakan campuran antara keberadaan serangga dewasa, ovisacs dan nimfa dari serangga tersebut. Kutu putih menutupi organ inangnya dengan membuat lapisan yang menutupi organ terinfeksi tersebut sehingga inangnya mengalami gangguan fotosintesis dan pertumbuhan. Pengendalian hama kutu putih atau mealybug oleh petani biasanya dengan penggunaan insektisida. Akan tetapi penggunaan insektisida pada konsentrasi tertentu akan menyebabkan efek samping pada lingkungan dan pada musuh alami mealybug itu sendiri. Mengingat penggunaan insektisida dapat menyebabkan terjadinya resistensi maka perlu ditemukan pengendalian hama yang lebih ramah lingkungan dalam jangka waktu panjang. Telah banyak teknik pengendalian alternatif yang telah ditelaah, antara lain dengan aplikasi menggunakan musuh alami. Musuh alami adalah organisme yang dapat membunuh organisme tertentu atau melemahkan organisme sehingga mengakibatkan kematian organisme tersebut, dalam hal ini hama kutu putih atau mealybug. Keragaman musuh alami pada populasi serangga hama kutu putih atau mealybug masih sedikit diteliti di Indonesia. Penelitian ini bertujuan untuk mengetahui keanekaragaman mealybug pada tanaman singkong serta keberadaan musuh alaminya.

\section{METODE PENELITIAN}

Waktu dan tempat penelitian. Penelitian dilaksanakan pada bulan Maret - Agustus 2018. Adapun tempat penelitian adalah 10 kecamatan di Kabupaten Banyuwangi dari 22 kecamatan dengan kisaran produksi sebesar $162-200 \mathrm{kuintal} / \mathrm{ha}$. Daerah penelitian dipilih berdasarkan peringkat sepuluh kecamatan dengan luas lahan singkong terbesar. Sedangkan untuk studi laboratorium dilaksanakan di Laboratorium Biologi FMIPA Universitas PGRI Banyuwangi serta Laboratorium Hama dan Penyakit Tumbuhan Fakultas Pertanian Universitas Jember.

Teknik pengambilan sampel. Metode yang digunakan dalam penelitian ini adalah metode observasi dengan melakukan pengambilan sampel secara acak (simple random sampling). Prosedur penelitian yang dilakukan adalah pengambilan sampel, 
pemeliharaan kutu putih (rearing), dan identifikasi kutu putih serta musuh alami. Pengambilan sampel kutu putih dan parasitoid dilakukan dengan mengambil sampel daun yang terinfeksi kutu putih di sepuluh kecamatan di wilayah Kabupaten Banyuwangi dan dilakukan tiga kali pengulangan. Daun terinfeksi kutu putih yang telah dikumpulkan, selanjutnya di-rearing.

Proses rearing. Proses rearing dilakukan dengan memasukkan daun yang terinfeksi kutu putih ke dalam wadah plastik yang pada bagian tutupnya tersambung dengan wadah plastik yang lebih kecil sebagai perangkap parasitoid. Seluruh permukaan wadah plastik besar dibungkus dengan menggunakan plastik warna hitam. Setelah 7 sampai 14 hari dalam pemeliharaan, parasitoid yang berada dalam tubuh kutu putih imago akan keluar dari tempat pemeliharaan, namun terperangkap dalam tutup sehingga parasitoid dapat diambil. Parasitoid yang muncul dikumpulkan dan dilakukan pencatatan terhadap jenis parasitoid yang ditemukan. Keberadaan predator hama dapat diamati pada saat pengamatan langsung di lapangan.

Teknik identifikasi. Untuk mengetahui nama musuh alami yang muncul, dilakukan identifikasi berdasarkan karakter morfologi [12]. Identifikasi kutu putih dilakukan berdasarkan karakter morfologi lilin kutu putih [13].

Analisis data. Indeks Shannon-Wiener digunakan untuk mengetahui keanekaragaman spesies pada setiap habitat, dengan rumus sebagai berikut [14].

$$
\mathrm{H}^{\prime}=-\Sigma \text { pi } \ln \mathrm{pi}, \mathrm{pi}=\mathrm{ni} / \mathrm{N}
$$

Keterangan:

$\mathrm{H}^{\prime}=$ Indeks Shannon Wiener

$\mathrm{ni}=$ Jumlah Individu untuk spesies yang diamati

$\mathrm{N}=$ Jumlah total Individu

Indeks keanekaragaman dikelompokkan pada tiga kriteria, yaitu jika $\mathrm{H}^{\prime}<1$, maka keanekaragaman rendah. Selanjutnya apabila $\mathrm{H}^{\prime}=1<\mathrm{H}^{\prime}<3$ maka keanekaragaman sedang dan apabila nilai $\mathrm{H}^{\prime}>3$ maka keanekaragaman tinggi.

Data bentuk penyebaran serangga kutu putih ditentukan oleh nilai $\mathrm{z}, \overline{\mathrm{x}}$, dan v. Nilai $\mathrm{z}$ didapatkan dengan rumus $z=(\bar{x}-v) /(\operatorname{std} / \sqrt{ } n)$. Nilai $\mathrm{z}$ menentukan bentuk penyebaran atau distribusi pada daerah tertentu. Jika nilai $\mathrm{z}$ adalah $-1.96>\mathrm{z}>1.96$, maka bentuk penyebaran serangga di daerah tersebut adalah acak. Jika nilai $\mathrm{z}$ terhitung berada di luar kisaran tersebut dan nilai rata-rata $(\overline{\mathrm{x}})$ lebih besar dari nilai keragaman (v), maka bentuk penyebarannya teratur. Sedangkan jika nilai z terhitung berada di luar kisaran tersebut dan nilai rata-rata $(\overline{\mathrm{x}})$ lebih kecil daripada nilai keragaman (v) maka bentuk penyebarannya mengelompok [15].

\section{HASIL DAN PEMBAHASAN}

Jenis kutu putih yang ditemukan. Dalam penelitian, dua jenis kutu putih yang didapatkan melalui hasil pengamatan langsung di lapangan dan pengambilan sampel daun yang terinfeksi kutu putih. Dua jenis kutu putih yang ditemukan adalah $F$. virgata dan $P$. marginatus. Dari semua lokasi pengambilan data, jumlah populasi $F$. virgata lebih rendah jika dibandingkan dengan populasi $P$. marginatus.

Ferrisia virgata. $F$. virgata tergolong dalam Ordo Hemiptera dan Famili Pseudococcidae. Karakter spesifik hama ini yaitu memiliki warna tubuh putih dan kuning, dengan lapisan lilin berwarna putih (Gambar 1), tepian tubuhnya terdapat seperti benangbenang kecil, serta pada bagian ekor memiliki dua benang yang lebih panjang dari benang lainnya di sekitar tubuh [16]. Hama ini bersifat polifag, imago betina dapat memproduksi minimal 64 butir telur [17] sampai dengan 737 [18] butir telur dalam waktu 3-4 jam. Waktu yang dibutuhkan untuk peralihan bentuk telur menjadi nimfa berkisar antara 4-9 hari. Individu jantan membutuhkan waktu 20-60 hari setelah nimfa menetas untuk menjadi imago dan individu betina akan menjadi imago dalam jangka waktu yang lebih pendek yaitu antara 20-45 hari setelah nimfa menetas. Ada perbedaan bentuk yang cukup signifikan antara $F$. virgata betina dan jantan. Betina berbentuk oval dengan strukur serupa lilin berwarna putih pada tubuhya; sebagian dari struktur lilin ini berbentuk menyerupai benang, juga ada ekor dari lilin tersebut. Individu jantan memiliki sayap, namun betinanya tidak. Tubuh imago jantan berbentuk lebih kurus dari imago betina dengan antena agak panjang. Imago betina memiliki siklus hidup selama 1-2 bulan, sedangkan imago jantan hanya bertahan hidup selama 1-3 hari. Selain kopulasi, perkembangbiakan hama ini dapat dilakukan secara partenogenesis oleh imago betina [19]. Kerusakan yang ditimbulkan oleh $F$. virgata 
diawali dengan munculnya gejala keriput pada bagian tanaman. Bagian tanaman yang terkena serangan akan berangsur menjadi kering dan mengalami keguguran daun [20].

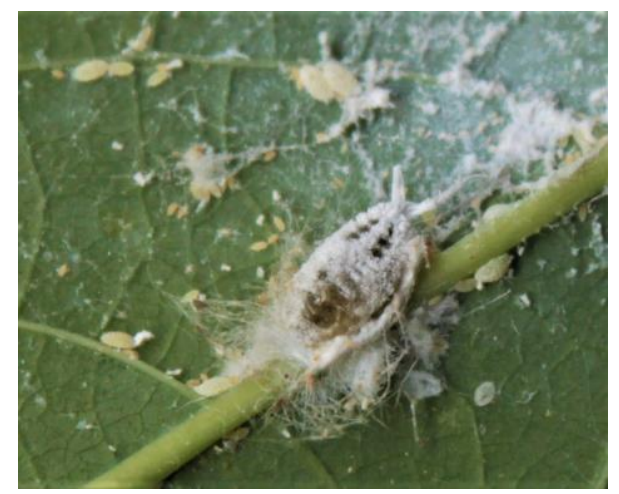

Gambar 1. Ferrisia virgata stage dewasa (dok. Pribadi)

Paracoccus marginatus. $P$. marginatus termasuk jenis kutu-kutuan yang seluruh bagian tubuhnya ditutupi oleh lapisan serupa lilin berwarna putih. Bentuk tubuh oval dengan umbaian seperti rambut-rambut putih berukuran pendek seperti yang ditunjukkan pada gambar 2. Hama ini sudah dapat dipisahkan antara individu jantan dan betina, individu jantan dan betina $P$. marginatus memiliki perbedaan dalam tahapan perkembangan hidup. $P$. marginatus betina melalui metamorfosis paurometabola (metamorfosis bertingkat), yang diawali dengan fase telur, fase nimfa yang terdiri dari instar pertama, instar kedua dan instar ketiga serta fase imago yang tidak mempunyai sayap. Individu jantan melalui proses metamorfosis holometabola (metamorfosis sempurna), yang terdiri dari fase telur, fase nimfa yang terdiri dari instar pertama hingga tahap instar ketiga yang berupa prapupa, dan instar keempat berupa pupa, kemudian stadium imago yang dilengkapi dengan sepasang sayap. Telur $P$. marginatus memiliki warna kuning kehijauan dengan bentuk bulat dan diselimuti oleh massa berstruktur serupa kapas dan menetas dalam jangka waktu kurang lebih 10 hari setelah ditempatkan [21]. P. marginatus menyerang tanaman dengan cara mengisap cairan pada bagian tanaman, dari buah sampai pucuk. Serangan $P$. marginatus pada pucuk tanaman mengakibatkan daun menjadi lebih sempit, kerdil dan mengalami pengeriputan seperti terbakar [20].

Musuh alami. Setelah melakukan rearing pada serangga hama kutu putih, musuh alami kutu putih yang berupa parasitoid tidak ditemukan. Sedangkan dari hasil pengambilan data dan pengamatan di lapangan hanya ditemukan satu predator dari kutu putih yaitu Lacewing dari spesies Hemerobius spp. Keberadaan musuh alami hama kutu putih ini diduga dipengaruhi oleh keanekaragaman hama kutu putih sebagai inang, keberadaan tanaman liar sebagai tempat berlindung dan sumber makanan alternatif bagi musuh alami tersebut. Beberapa predator lain dari kutu putih yang dapat mengendalikan pertambahan populasi hama kutu putih antara lain Hyperaspis notata Mulsant dan $H$. jucundan (Coleoptera: Coccinellidae) [22]. Tidak adanya musuh alami kutu putih yang berupa parasitoid disebabkan karena hama kutu putih sebagai inang dari parasitoid tersebut merupakan hewan eksotis yang bukan asli Indonesia. Sehingga musuh alaminya juga tidak dapat ditemukan secara alami di Indonesia. Hama kutu putih yang di-rearing tidak terparasit, sehingga tidak ada parasitoid yang muncul setelah proses rearing dilakukan. Upaya pengendalian hayati yang mulai diterapkan adalah dengan pelepasan parasitoid Anagyrus lopezi sebagai musuh alami dari hama kutu putih.

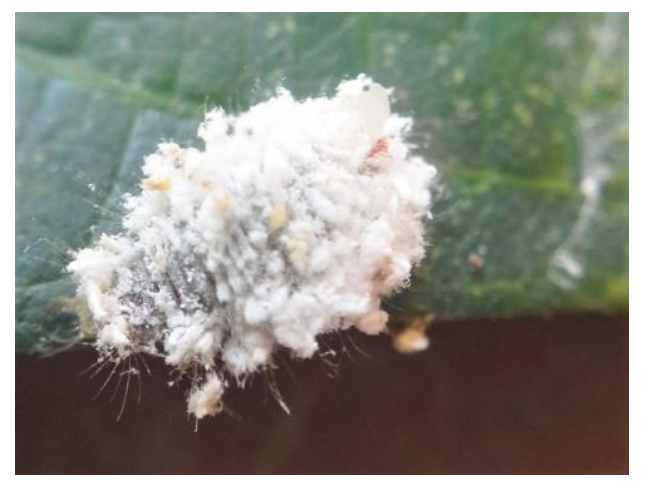

Gambar 2. Paracoccus marginatus stage dewasa (dok. Pribadi)

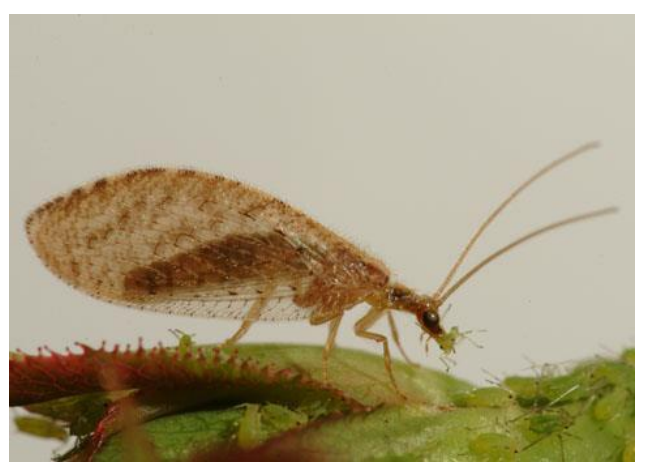

Gambar 3. Hemerobius sp. [24]

Hasil analisis. Indeks keanekaragaman kutu putih pada tanaman singkong di Kabupaten Banyuwangi hampir sama pada sepuluh lokasi penelitian, tertinggi ditemukan 
di Kecamatan Wongsorejo, sedangkan indeks keanekaragaman terendah ditemukan di Kecamatan Cluring.

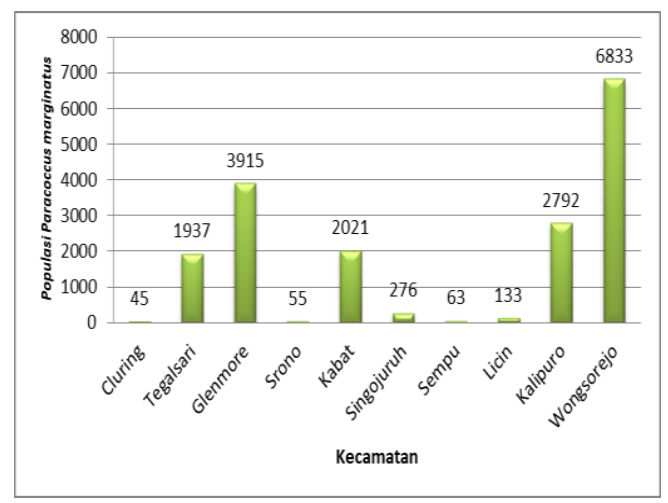

Gambar 4. Distribusi Ferrisia virgata

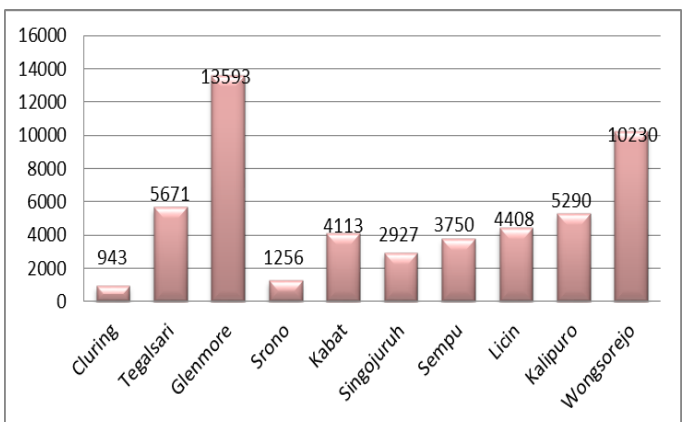

Gambar 5. Distribusi Paracoccus marginatus

Jumlah individu dan indeks keanekaragaman kutu putih pada tanaman singkong di Kecamatan Wongsorejo dan Glenmore lebih tinggi dibandingkan dengan lokasi lainnya. Hal ini disebabkan karena populasi inang di Wongsorejo dan Glenmore. Populasi tanaman singkong yang tinggi di lokasi ini disebabkan tanaman singkong ditanam di area tegalan dengan populasi gulma rendah, terdiri dari tanaman bayam duri dan rerumputan. Keberadaan gulma yang rendah di lokasi ini disebabkan karena ada proses penyiangan secara berkala yang dilakukan oleh petani tanaman singkong. Selain itu, jumlah individu kutu putih dan indeks keanekaragaman di Kecamatan Wongsorejo lebih tinggi daripada sembilan lokasi lainnya. Hal ini disebabkan karena populasi tanaman inang yakni tanaman singkong di Kecamatan Wongsorejo lebih besar dibandingkan dengan populasi tanaman singkong di ketiga lokasi lainnya serta dipengaruhi juga oleh keberadaan tanaman sekitar.

Bentuk persebaran. Dari hasil penghitungan nilai rata-rata dan keragaman spesies, bentuk penyebaran $F$. virgata dan $P$. marginatus di 10 kecamatan yang diobservasi menunjukkan perilaku persebaran yang mengelompok. Bentuk penyebaran mengelompok ini terjadi pada tingkat lanjut dari penghunian suatu lahan pertanaman oleh hama [15]. Artinya, bentuk penyebaran mengelompok ini terjadi jika suatu hama sudah menempati suatu lahan pertanaman pada waktu yang cukup lama. Kondisi ini sesuai dengan ekosistem lingkungan lokasi yang mendukung spesies untuk berkembang.

Tabel 1. Data bentuk persebaran Ferrisia virgata

\begin{tabular}{lrl}
\hline \multicolumn{1}{c}{ Lokasi } & \multicolumn{1}{c}{$\begin{array}{l}\text { Indeks } \\
\text { Persebaran }\end{array}$} & $\begin{array}{c}\text { Pola } \\
\text { Persebaran }\end{array}$ \\
\hline Cluring & $-7,69$ & Mengelompok \\
Tegalsari & $-160,27$ & Mengelompok \\
Glenmore & $-280,70$ & Mengelompok \\
Srono & $-6,99$ & Mengelompok \\
Kabat & $-207,55$ & Mengelompok \\
Singojuruh & $-36,41$ & Mengelompok \\
Sempu & $-2,63$ & Mengelompok \\
Licin & $-22,85$ & Mengelompok \\
Kalipuro & $-319,20$ & Mengelompok \\
Wongsorejo & $-798,81$ & Mengelompok \\
\hline
\end{tabular}

Tabel 2. Data bentuk persebaran Paracoccus marginatus

\begin{tabular}{lrl}
\hline \multicolumn{1}{c}{ Lokasi } & $\begin{array}{c}\text { Indeks } \\
\text { persebaran }\end{array}$ & $\begin{array}{c}\text { Pola } \\
\text { persebaran }\end{array}$ \\
\hline Cluring & $-98,49$ & Mengelompok \\
\hline Tegalsari & $-389,21$ & Mengelompok \\
Glenmore & $-1779,49$ & Mengelompok \\
\hline Srono & $-148,85$ & Mengelompok \\
Kabat & $-485,62$ & Mengelompok \\
\hline Singojuruh & $-418,06$ & Mengelompok \\
Sempu & $-388,53$ & Mengelompok \\
Licin & $-617,83$ & Mengelompok \\
\hline Kalipuro & $-1160,78$ & Mengelompok \\
Wongsorejo & $-1069,57$ & Mengelompok \\
\hline
\end{tabular}

Keanekaragaman kutu putih dipengaruhi oleh populasi tanaman singkong, keberadaan gulma, serta keberadaan tanaman sekitar. Gulma atau tanaman liar merupakan komponen yang cukup penting dalam agroekosistem karena dapat memengaruhi dinamika populasi hama. Tanaman liar yang sesuai dapat menjadi host atau inang alternatif bagi hama. Keanekaragaman kutu putih juga tidak terlepas dari pengaruh faktor abiotik antara lain cuaca, suhu dan curah hujan. Kutu putih dapat berkembangbiak secara optimal pada kisaran suhu $28^{\circ} \mathrm{C}$ [23]. Hama kutu putih ini juga mengalami ledakan populasi pada saat cuaca panas dan mengalami penghambatan populasi serta perkembangbiakan jika curah hujan dan intensitas hujan cukup tinggi. 
Populasi dan keanekaragaman kutu putih juga dipengaruhi oleh keberadaan musuh alami.

\section{KESIMPULAN}

Dari hasil penelitian ini, diperoleh kesimpulan bahwa pada sepuluh lokasi di Kabupaten Banyuwangi ditemukan dua spesies kutu putih yaitu $P$. marginatus dan $F$. virgata, ditemukan satu spesies predator kutu putih jenis Lacewing Hemerobius spp, serta tidak ditemukan adanya musuh alami berupa parasitoid. Indeks keanekaragaman kutu putih di Kabupaten Banyuwangi masuk dalam kategori sedang dengan pola persebaran mengelompok.

\section{UCAPAN TERIMA KASIH}

Penulis mengucapkan terima kasih kepada Kementrian Ristek Dikti, Penelitian Dosen Pemula tahun anggaran 2017 tahun pelaksanaan 2018 .

\section{DAFTAR PUSTAKA}

[1] Purwono, Purnamawati H (2007) Budidaya 8 Jenis Tanaman Pangan Unggul. Jakarta (ID): Penebar Swadaya. hlm 58.

[2] Direktorat Jenderal Tanaman Pangan (2012) Pedoman Teknis Pengelolaan Produksi Ubikayu. Jakarta (ID): Direktorat Jenderal Tanaman Pangan, Kementrian Pertanian.

[3] Soetanto NE (2008) Tepung Kasava dan Olahannya. Kanisius. hlm 81. Yogyakarta (ID).

[4] Rauf A (2008) Hama kutu putih Paracoccus marginatus. Pusat Penelitian Ilmu Hama Tanaman. Institut Pertanian Bogor. Bogor

[5] Shepard BM, Barrion AT, Litsinger JA (1995) Serangga, Laba-laba dan Patogen yang membantu. Untung K. Wirosuhardjo S, Penerjemah. Jakarta: Program Nasional Pengendalian Hama Terpadu, Bappenas. Terjemahan dari: Helpful Insects, Spiders, and Pathogens.

[6] Winotai A, Goergen G, Tamo M, Neuenschwander P (2010) Cassava mealybug has reached Asia. Biocont News Info 31(2): 10N-11N.

[7] Parsa S, Kondo T, Winotai A (2012) The cassava mealybug (Phenacoccus manihoti) in Asia: first records, potential distribution, and identification key. PLOS ONE 7 (10): e47675.

[8] Muniappan R, Shepard BM, Watson GW, Carner GR, Rauf A, Sartiami D, Hidayat P, Afun JVK, Goergen G, Rahman AKMZ (2011) New records of invasive insects (Hemiptera: Sternorrhyncha) in southern Asia and West Africa. J Agric Urban Entomol. 26 (4): 167- 174.

[9] Badan Pusat Statistik Kabupaten Banyuwangi (2016) Banyuwangi Dalam Angka 2015. ISSN 02155319

[10] Amarasekare KG, Mannion KM, Osborne LS, Epsky ND (2008) Life history of Paracoccus marginatus (Hemiptera: Pseudococcidae) on four host plant species under laboratory conditions. Environ Entomol. 37: 630-635.

[11] Calatayud PA, Le Rü B (2006) Cassava mealybug interactions. Paris (FR): Institut De Recherche Pour Le Développement.

[12] Flint LM, Dreistadt HS (1998) Natural enemies handbook, the illustrated guide to biological pest control. UC Division of Agricultural and Natural Resources. University of California Press.

[13] Osborn LS (2010) Mealybugs. MidFlorida Research and Education Center. University of Florida.

[14] Magurran AE (2004) Measuring biological diversity. Blackwell Science Ltd. Oxford.

[15] Krebs CJ (1989) Ecology, the experimental analysis of distributions and abundance. Harper and Row Publication Inc. New York.

[16] Chandra D (2008) Inventarisasi hama dan penyakit pada pertanaman Jarak pagar (Jathropa curcas Linn) di Lampung dan Jawa Barat. Tidak Diterbitkan. Skripsi. Program Studi Hama dan Penyakit Tumbuhan, Fakultas Pertanian, Institut Pertanian Bogor.

[17] Awadallah KT, Ammar ED, Tawafik MFS, Rashad A (1979) Life history of the white mealybug Ferrisia virgata (Ckll.) (Homoptera: Pseudococcidae). Zeitschrift für Deutsche Entomologen 26:101-110

[18] Ghose SK, Paul PK (1972) Observations on the biology of the mealybug, Ferrisia virgata (Cockerell) (Pseudococcidae: Hemiptera). Proceedings of the Zoological Society (Calcutta) 25: 39-48.

[19] Kalshoven, LGE (1981) Pest of crop in Indonesia. PT. Ichtiar Baru - Van Hoeve. Jakarta. 
[20] Bellotti AC, Melo EL, Arias B, Herrera CJ, Hernandez MDP, and Holguin CM, Guerrero JM, Trujillo H (2003) Biological control in the neotropics: a selective review with emphasis on cassava. Second International Symposium on Biological Control of Arthropods 1: 206-277.

[21] Walker A, Hoy M, Meyerdirk (2003) Papaya mealybug (Paracoccus marginatus Williams and Granara de Willink (Insecta: Hemiptera; Pseudococcidae)). EENY - 302. Featured creatures. Entomology and Nematology Department, Florida Cooperative Extension Service, Institute of Food and Agricultural Sciences, University of Florida. Gainesville, FL. Available from http://if-srvv-

edis.ifas.ufl.edu/pdffiles/in/in57900.pdf. diakses tanggal 5 April 2014.

[22] Purnomo H (2010) Pengantar Pengendalian Hayati. Andi. Yogyakarta.

[23] Zakaria F (2014) Kutu putih Phenacoccus manihoti, hama "impor" baru pada tanaman ubi kayu. http://tanamanpangan.pertanian.go.id/ditli ntp/berita-160-kutu-putih-phenacoccusmanihoti-hama\%E2\%80\%9Cimpor\%E2\%80\%9D-barupada-tanaman-ubi-kayu.html Diakses pada tanggal 26 Januari 2015.

[24] Bryant PJ (2008) Brown Lacewing, Hemerobius sp. http://nathistoc.bio.uci.edu/neuropt/Hemer obius.htm diakses pada tanggal 9 November 2020. 